International Research Journal of Management, IT \& Social Sciences
Available online at https://ijcujournals.us/journals/index.php/irjmis
Vol. 6 No. 1, January 2019, pages: $55 \sim 62$
ISSN: 2395-7492
https://doi.org/10.21744/irjmis.v6n1.581

\title{
Interpersonal Communication between Lecturers with Students in Wira Bhakti Denpasar College
}

I Nengah Merta

Article history:

Received: 27 July 2018

Accepted: 30 November 2018

Published: 9 January 2019

\section{Keywords:}

interpersonal communication; lecturers;

self-concept;

social change;

students;

\begin{abstract}
This study examines "Interpersonal Communication between Lecturers and Students at Wira Bhakti Denpasar College". Interpersonal Communication Ability is a skill that must be carried by individuals in interacting with individuals in interacting with other individuals or groups of individuals. Interpersonal ability is what someone uses when communicating and dealing with other people face to face. Social Communication implies that communication is important to build self-concept, for survival, selfactualization, to gain happiness, to avoid pressure and dependence, among others, through entertaining communication and fostering relationships. Through social communication can work together with community members (family, study groups, colleges, village, city, and the country as a whole) to achieve common goals. The problem in this study is, How do leaders implement interpersonal communication which includes; openness, supportive behavior, positive behavior (positiveness), empathy (empathy) and equality at Wira Bhakti Denpasar College. The purpose of this study was to find out and describe the interpersonal communication of lecturers with students in an effort to build and improve performance at Wira Bhakti Denpasar College. This study uses a qualitative descriptive method, using proportional sampling techniques consisting of the Chairperson of Wira Bhakti College, Assistant Chairperson, Head of Study Programs, Lecturers and Students. Based on the results of the analysis and discussion it can be concluded the research findings include: Lecturers Wira Bhakti Denpasar College with students have implemented interpersonal communication that includes, openness, supportive behavior, positive behavior, empathy, and equality, it is evident that the academic community trust each other, togetherness, warmth, comfort felt appreciated in doing their respective assignments, so Wira Bhakti Denpasar College increasingly advanced.
\end{abstract}

2395-7492@ Copyright 2019. The Author. Published by SLOAP. This is an open-access article under the CC-BY-SA license (https://creativecommons.org/licenses/by/4.0/) All rights reserved.

\section{Author correspondence:}

I Nengah Merta,

Wira Bhakti Denpasar College, Jalan Cempaka No. 6 Denpasar 89233, Indonesia

Ph. (+62361) 235778 Tel. +6282247303361

Email address: nengahwirabhakti@gmail.com

${ }^{a}$ Wira Bhakti Denpasar College, Jalan Cempaka No. 6, Denpasar 89233, Indonesia 


\section{Introduction}

In their lives, humans are always involved in communication activities. In context, interpersonal communication is described as a communication between two individuals or a few individuals, which interact with each other, give feedback to one another. Therefore communication is an act of human beings born with full awareness, even human beings are actively born because there are certain aims or objectives (Pinatih et al., 2018; Suryasa, 2014; Liu, 2018). Interpersonal communication is the process of exchanging information between someone with at least one other person or usually between two people who can be immediately known to return it" (Muhammad, 2005). Based on preliminary research that life communication is the main requirement in human life. No human has given up his life to communicating with each other. Therefore, social communication is very important in human life, in general, to help him interact with others, because humans are created as social beings.

People who have never communicated with other people will certainly get lost because he did not have time to organize himself in a social environment. Communication that allows individuals to build a referral framework and use it as a guide to interpret, whatever situation they face. Communication also allows him to learn and apply adaptive strategies to deal with problematic situations that might occur.

\section{Literature Review}

Case studies of interpersonal communication between groups of people in the country have been studied by many local and foreign researchers. However, special research on interpersonal communication between lecturers and students at Wira Bhakti Denpasar College is interesting to study because it has never been appointed as a research study to obtain research findings.

Based on the search for studies of interpersonal communication in Indonesia, it was studied Bahriyah (2012), entitled "Interpersonal Communication Tour Guide in Introducing Indonesia to Foreign Tourists". The results of this study explain that interpersonal communication can provide a sense of comfort to foreign tourists visiting Indonesia with Indonesia's wonderful guide, tourists want to travel according to their own budget and the convenience of all Indonesian tourism destinations.

Also, the research of Ningrum (2014) entitled "Perception of Social Support and Interpersonal Communication Ability in Lung Tuberculosis Patients in Denpasar". In it, interpersonal communication is often experienced obstacles, caused by an illness, such as pulmonary tuberculosis. Pulmonary tuberculosis is a direct infectious disease caused by the Mycobacterium tuberculosis germ. Patients with pulmonary tuberculosis experience anxiety, fear, and shame which inhibits interpersonal communication, where patients with pulmonary tuberculosis have difficulty communicating what is felt and thought about the disease experienced. One of the treatments is social support, to reduce anxiety, fear, shame towards others. So, the focus of the study is that interpersonal communication often experiences obstacles, which are caused by an illness for which social support is very potent as a cure. While this research is specifically "Interpersonal Communication between lecturers and students at Wira Bhakti Denpasar Collage" as a study of current interpersonal communication (Aryani, 2018 \& Umrah et al., 2018).

\section{Materials and Methods}

Types and Data Sources

The data used in this study are:

a) Primary data, namely data and information obtained directly from the source/respondent. This data was obtained by conducting interviews from lecturers and students in the Wira Bhakti Denpasar College. By using a proportional sampling technique with a sample of 20 lecturers and 16 students.

b) Secondary data, namely data and supporting information obtained from the Wira Bhakti Denpasar College Secretariat and other relevant data.

\section{Research Location}

The research location was at Wira Bhakti Denpasar College by observing and mapping the academic community in a measurable manner. The time of observation as an object of analysis is the condition of 12 months from January to December running in 2018. Consideration of the use of 2018 is taken to facilitate recording of information on 
respondents, namely, Chairperson of Wira Bhakti Denpasar College, Assistant Chairperson, Study Program, Lecturers and Students.

\section{Research Instruments}

The instruments used in this study were descriptive research through literature surveys and field surveys and in-depth interviews. The interviews conducted were open questions and closed questions ended.

\section{Method of Data Analysis}

The analytical method used in this study includes several methods according to the research objectives as follows:

\section{Theory of Social Exchange John Thibaut and Harlod Kelley and Peter Blau (2004)}

Social exchange theories include John Thibaut and Harlod Kelley and Peter Blau (2004). Based on this theory, the community is included in the exchange relationship with other people so that the reward is obtained. In other words, the exchange relationship between Wira Bhakti Denpasar College and lecturers and students will produce a reward in the form of compensation for the lecturers and students to get the knowledge they have learned while in college and diplomas as a symbol of success. Social exchange theory is a theory in the social sciences that states that in social relations there are elements of rewards, sacrifices, and benefits that influence each other. This theory explains how the Wira Bhakti Denpasar College with lecturers and students views the mutually beneficial relationship according to the assumption that the balance between what is given in the relationship is reflected and what is released from the relationship, the type of relationship that is carried out, the opportunity to have more relationships good with other people. The point of view of social exchange states that people calculate the overall value of a relationship by subtracting the sacrifice from the award received (Monge, 2003). The assumptions of social exchange theory regarding the nature of the academic community are as follows: Lecturers and students achieve appreciation and avoid punishment. The idea is that humans seek rewards and avoid punishment in accordance with the conceptualization of reduced motivation (Roloff, 2001). This approach holds that people's behavior is motivated by an internal push mechanism. When people feel this urge, they are motivated to reduce it, and the process of implementing it is fun. Humans are rational beings. That humans are rational beings is an important assumption for social exchange theory. The standards used by humans to evaluate sacrifices and rewards vary over time and from one person to another. The third assumption shows that this theory must consider the existence of diversity. There is no single standard that can be used by everyone to determine what sacrifice and appreciation are.

The assumptions made by social exchange theory about the nature of a relationship: (1) Relationships are interdependent, in a relationship when a participant takes an action, both the participant and their relationship as a whole will be affected. (2) Life-related is a process. The importance of time and change in the life of a relationship. In particular time influences exchange because past experiences lead to judgments about rewards and sacrifices, and this judgment influences subsequent exchanges (Berger, 2014; Stuart et al., 1999; Jo et al., 2005; Gudykunst et al., 1996).

\section{Social Category Theory Melvin L. DeFleur (2006)}

Theories of social categories are collections, groups, or social categories in the community that will provide a uniform response to media exposure. DeFleur (2006), as the expert who presented this theory, said that social category theory states that there are associations, the social category in an urban-industrial society whose behavior when exposed to certain stimulants will be almost uniform. The basic assumption of social category theory is a sociological theory which states that although modern lecturers and students are heterogeneous in nature, residents who have the same number of characteristics will have the same traditional lifestyle. Characteristics: age, sex, income, education, settlements or religious relationships. Equations of style, orientation and behavior will be related to a symptom as in the mass media in uniform behavior. Members of a particular category will choose the same communication, and respond in almost the same way. This theory is consistent with it seems to originate from the general sociology of mass media. The relationship between mass communication and interpersonal communication can be seen in the effects of socialization from the mass media. Mass media is one of the sources where people learn about the surrounding community. In this case, the mass media influence the way lecturers and students in Wira Bhakti College relate to each other at the interpersonal level. Elements of the concept of self-awareness in social interaction between humans such as (1) Self-concept, namely how to see yourself, usually this is done by classifying the characteristics of personal traits, characteristics of social traits, and social roles. (2) Personal characteristics are traits possessed, at least in the perception

Merta, I. N. (2019). Interpersonal communication between lecturers with students in Wira Bhakti Denpasar College. International Research Journal of Management, IT and Social Sciences, 6(1), 55-62. https://doi.org/10.21744/irjmis.v6n1.581 
of oneself. These characteristics can be physical (male, female, tall, low, beautiful, handsome, fat) or can also refer to certain abilities (clever, quiet, capable, ignorant, learned) self-concept is very closely related to knowledge. If someone's knowledge is high, then one's self-concept is also high. Conversely, if someone's knowledge is low, a person's self-concept is also low. (3) Social characteristics, namely the traits that are displayed in relationships with other people (friendly or curt, extroverted or introverted, talkative or quiet, attentive or indifferent).

\section{Observation Technique and Interview}

Observations are carried out by making observations directly in the field so that they can see and observe more carefully the conditions of the location at Wira Bhakti Denpasar College. In-depth interview (In-depth interview) with several informants that have been set by 36 people.

Documentation Study

Documentation studies, namely the technique of collecting data by taking a number of documents or past records, Stispol Wira Bhakti Denpasar and relevant agencies.

\section{Results and Discussions}

\section{Theory of Social Exchange John Thibaut and Harlod Kelley and Peter Blau (2004)}

Interpersonal communication is communication that only two people, such as husband and wife, two colleagues, two close friends, teacher-students and so on, (Mulyana, 2009). So it can be said that interpersonal communication is the process of delivering information, thoughts and certain attitudes between lecturers and students or with the head of the department that happens to change the message both as communicant and communicator with the aim of achieving mutual understanding, about the issues to be discussed which eventually changes behavior is expected. Social exchange theory from Thibaut et al., (2004). Based on this theory, the academic community is included in the exchange relationship with other people so that the reward is obtained. In other words, the exchange relationship between Wira Bhakti and lecturers and students will produce a reward in the form of compensation for the lecturers and students to get the knowledge they have learned while in college and diplomas as a symbol of success. Social exchange theory is a theory in the social sciences that states that in social relations there are elements of rewards, sacrifices, and benefits that influence each other. This theory explains how Wira Bhakti Denpasar College tertiary institutions with lecturers and students view mutually beneficial relationships according to the assumption that the balance between what is given in the relationship is reflected and what is released from the relationship, the type of relationship that is made, the opportunity to have more relationships good with other people. The point of view of social exchange states that people calculate the overall value of a relationship by subtracting the sacrifice from the award received (Monge, 2003). The success in conveying information is largely determined by the nature and quality of the relationships among the individuals involved and contains five general qualities considered, namely: openness, the quality of openness refers to at least three aspects of interpersonal communication. First, effective interpersonal communicators must be open to the people they are interacting with. This does not mean that people have to open all history of their lives but there must be a willingness to disclose information that is usually hidden, provided that this self-disclosure is appropriate. The second refers to the communicator's willingness to react honestly to the stimulus that comes. The third aspect concerns the ownership of feelings and thoughts. The meaning is open to recognizing that the feelings and thoughts that people throw are indeed theirs and must be accounted for. Empathy (empathy), as a person's ability to know what is being experienced by someone else at a certain time, from the other person's perspective. People who are empathetic are able to understand the motivations and experiences of others, their feelings and attitudes, and their hopes and desires in the future. This understanding of empathy will make one more capable of adjusting his communication, (Backrack in Devito, 2002). The attitude of support (supportiveness), an effective interpersonal relationship is a relationship where there is a supportive attitude (supportiveness). Supportive attitude is characterized by attitude (1) descriptive, is to perceive a communication as a request for information or a description of a particular event and not feel it as a threat. (2) spontaneously, people who are spontaneous in their communication and forthright and open in expressing their thoughts usually get the same reaction and (3) provisional, meaning to be tentative and open-minded and willing to hear opposing views and willing to change positions if circumstances require it. If someone is sure to be unshakable and closed-minded, it will encourage the listener's defensive behavior. Positive attitude (positiveness), positive attitude in interpersonal communication there are two ways, namely: (1) expressing a positive attitude refers 
to at least two aspects of interpersonal communication. First, interpersonal communication is nurtured if people have a positive attitude towards themselves and Second, positively encourage people who are friends who interact and equality, interpersonal communication will be more effective if the atmosphere is equal, meaning that there must be a tacit acknowledgment that both parties are both valuable and valuable and that each party has something important to contribute. Effective communication is characterized by good interpersonal relationships or emotional relationships. Communication failure occurs when the content of the message is understood, but the relationship between the communicant becomes damaged. If someone is gathered in one group that has similarities with him, then someone will feel happy, and open. Conversely, if he is gathered with people he hates, then it will make him feel tense, restless, and uncomfortable. Thus someone will close themselves and avoid communication or want to immediately end the communication (Devito in Rachmat, 2011). From the analysis above it can be said that social exchange theory states that in social relations there are elements of rewards, sacrifices, and benefits that influence each other. The exchange relationship between Wira Bhakti and lecturers and students will produce a reward in the form of compensation for lecturers and students in accordance with the previous agreement.

\section{Social Category Theory Melvin L. DeFleur (2006)}

Theories of social categories are collections, groups, or social categories in the community that will provide a uniform response to media exposure. DeFleur (2006), stated that the existence of associations, social categories in an urban-industrial society whose behavior when exposed to certain stimulants will be almost uniform. The relationship between mass communication and interpersonal communication is described as an intervening variable between mass media and behavior change. Another relationship between mass communication and interpersonal communication can be seen between the roles that complement each other between mass media channels and interpersonal communication when a person decides to accept or reject innovation. The relationship between mass communication and interpersonal communication can be seen in the effects of socialization from the mass media. Mass media is one of the sources where people learn about the surrounding community. In this case, the mass media influence the way lecturers and students in Wira Bhakti Denpasar College relate to each other at the interpersonal level. Elements of the concept of selfawareness in social interaction between humans such as (1) Self-concept, namely how to see yourself, usually this is done by classifying the characteristics of personal traits, characteristics of social traits, and social roles. (2) Personal characteristics are traits possessed, at least in the perception of oneself. These characteristics can be physical (male, female, tall, low, beautiful, handsome, fat) or can also refer to certain abilities (clever, quiet, capable, ignorant, learned) self-concept is very closely related to knowledge. If someone's knowledge is high, then one's self-concept is also high. Conversely, if someone's knowledge is low, a person's self-concept is also low. (3) Social characteristics, namely the traits that are displayed in relationships with other people (friendly or curt, extroverted or introverted, talkative or quiet, attentive or indifferent), etc.) This affects social roles, namely everything that includes relationships with other people and in certain communities. (4) Social roles, when social roles are part of self-concept, then social relationships are defined with others, such as father, wife, or teacher. This social role can also be related to culture, ethnicity, or religion. (5) Different selves, namely someone when he performs various activities, interests, and social relations. When involved in interpersonal communication, have two self-concepts in themselves, such as perceptions about self, and perceptions of other people's perceptions of them.

From the discussion above it can be said that the basic assumption of social category theory is a sociological theory which states that although modern lecturers and students are heterogeneous in nature, residents who have a number of the same characteristics will have the same traditional lifestyle. Characteristics: age, sex, income, education, settlements or religious relationships. Equations of style, orientation, and behavior will be related to a symptom as in the mass media in uniform behavior. Members of a particular category will choose the same communication, and respond in almost the same way. This theory is consistent with it seems to originate from the general sociology of mass media.

\section{Conclusion}

First, social exchange theory states that in social relations there are elements of rewards, sacrifices, and benefits that influence each other. The exchange relationship between Wira Bhakti Denpasar College and lecturers and students will produce a reward in the form of compensation for lecturers and students given by the Wira Bhakti Denpasar College.

Merta, I. N. (2019). Interpersonal communication between lecturers with students in Wira Bhakti Denpasar College. International Research Journal of Management, IT and Social Sciences, 6(1), 55-62. 
Second, the basic assumption of social category theory is sociological theory which states that even though modern lecturers and students in the Wira Bhakti Denpasar College are heterogeneous, residents who have a number of similar characteristics will have the same traditional lifestyle. Characteristics: age, sex, income, education, settlements or religious relationships. Equations of style, orientation, and behavior will be related to a symptom as in the mass media in uniform behavior.

Conflict of interest statement and funding sources

The author declared that he has no competing interest. The study was financed by personal funding.

Statement of authorship

The author has a responsibility for the conception and design of the study. The author has approved the final article.

\section{Acknowledgments}

The author would like to thank the College for their support in completing the present article. The thank also goes to the editorial for their valuable time, support as well as advice. 


\section{References}

Arni, M. (2005). Komunikasi organisasi. Jakarta: Bumi Aksara.

Aryani, N. L. (2018). Implementation of communication ethics in building social harmony. International Journal of Social Sciences and Humanities, 2(1), 147-156.

Berger, J. (2014). Word of mouth and interpersonal communication: A review and directions for future research. Journal of Consumer Psychology, 24(4), 586-607. https://doi.org/10.1016/j.jcps.2014.05.002

Defleur, M. L. (2007). Raising the Question\# 5 What Is Tenure and How Do I Get It?. Communication Education, 56(1), 106-112. https://doi.org/10.1080/03634520601081263

DeVito, C. L. (2011). On the universality of human mathematics. Communication with Extraterrestrial Intelligence, 439-448.

DeVito, J. A. (2002). The interpersonal communication reader. Allyn and Bacon.

Gudykunst, W. B., \& Shapiro, R. B. (1996). Communication in everyday interpersonal and intergroup encounters. International journal of intercultural relations, 20(1), 19-45. https://doi.org/10.1016/01471767(96)00037-5

Henry, K. (1931). U.S. Patent No. 1,833,426. Washington, DC: U.S. Patent and Trademark Office.

Jo, S., \& Shim, S. W. (2005). Paradigm shift of employee communication: The effect of management communication on trusting relationships. Public Relations Review, 31(2), 277-280. https://doi.org/10.1016/j.pubrev.2005.02.012

Liu, X. (2018). International communication of intangible cultural heritage in central plains: a case study of Chinese Wushu. International Journal of Social Sciences and Humanities, 2(3), 196-204. https://doi.org/10.29332/ijssh.v2n3.238

Monge, P. R., Contractor, P. S., \& Contractor, N. S. (2003). Theories of communication networks. Oxford University Press, USA.

Mulyana, R. (2009). Penanaman etika lingkungan melalui sekolah perduli dan berbudaya lingkungan. Jurnal Tabularasa, 6(2), 175-180.

Ningrum, M. J. S., \& Sukmayanti, L. M. K. (2014). persepsi dukungan sosial dan kemampuan komunikasi interpersonal pada pasien tuberkulosis paru di denpasar. Jurnal Psikologi Udayana, 1(3), 429-439.

Pinatih, I. D. S., Pratiwi, N. I., \& Ekaresty, P. (2018). The second concert of powers: managing US-China competition on the Korean peninsula conflict in terms of international communication perspective. International Research Journal of Management, IT and Social Sciences, 5(6), 17-25. https://doi.org/10.21744/irjmis.v5n6.305

Rachmat, K. (2006). Teknik praktis riset komunikasi. Jakarta, PT Kencana Prenada Media Group.

Roloff, M. E., \& Anastasiou, L. (2001). Interpersonal communication research: An overview. Annals of the International Communication Association, 24(1), 51-70. https://doi.org/10.1080/23808985.2001.11678981

Roloff, M. E., Soule, K. P., \& Carey, C. M. (2001). Reasons for remaining in a relationship and responses to relational transgressions. Journal of Social and Personal Relationships, 18(3), 362-385. https://doi.org/10.1177\%2F0265407501183004

Stuart, S., \& Noyes Jr, R. (1999). Attachment and interpersonal communication in somatization. Psychosomatics, 40(1), 34-43. https://doi.org/10.1016/S0033-3182(99)71269-7

Suryasa, I. W. (2014). Critical Review on Telephone Conversation in Greek and German: Attending to the Relationship Aspect of Communication. International Research Journal of Management, IT and Social Sciences, 1(1), 30-36.

Thibaut, J. (1959). The Social Psychology of Groups. New York: Routledge.

Umrah, D. M., Mahyuni, -, \& Syahdan, -. (2018). Communication strategy for English guides: tourism area in Lombok island. International Journal of Social Sciences and Humanities, 2(3), 117-124. https://doi.org/10.29332/ijssh.v2n3.217

Merta, I. N. (2019). Interpersonal communication between lecturers with students in Wira Bhakti Denpasar College. International Research Journal of Management, IT and Social Sciences, 6(1), 55-62. https://doi.org/10.21744/irjmis.v6n1.581 


\section{Biography of Author}

\begin{tabular}{|l|l|}
\hline & $\begin{array}{l}\text { I Nengah Merta, S.Sos, M.Si. is an associate professor, registered No. 0831126601. He } \\
\text { was born in Bangli, 31 December 1966. He lives at Jalan Buana Raya/Surya Buana B4 } \\
\text { Denpasar, Ph. +6282247303361. His office is at Jalan Cempaka No. 6 Denpasar, Telp. } \\
+62361235778 . \text { He graduated her bachelor degree in STISPOL Wira Bhakti Denpasar, } \\
\text { State Administration, 1995. He finished his master degree in Universitas Gadjah Mada, } \\
\text { Public Administration, 2001. } \\
\text { Email: nengahwirabhakti@gmail.com }\end{array}$ \\
\hline
\end{tabular}

